\title{
Assessment of NADPH-diaphorase stained myenteric neurons of the jejunum of diabetic rats supplemented with ascorbic acid ${ }^{1}$
}

\author{
Sônia M. Silverio ${ }^{2}$, Renata de B. Mari ${ }^{3}$, Naianne K. Clebis ${ }^{4}$, Juliana R. Scoz ${ }^{2}$, \\ Ricardo de M. Germano ${ }^{2}$, Fernanda Agreste $^{3}$, Pedro Primo Bombonato ${ }^{3}$ and \\ Sandra R. Stabille $2^{*}$
}

\begin{abstract}
Silverio S.M., Mari R.B., Clebis N.K., Scoz J.R., Germano R.M., Agreste F., Bombonato P.P. \& Stabille S.R. 2008. Assessment of NADPH-diaphorase stained myenteric neurons of the jejunum of diabetic rats supplemented with ascorbic acid. Pesquisa Veterinária Brasileira 28(2):95-102. Departamento de Ciências Biológicas, UNIPAR, Campus-Paranavaí, Av. Huberto Brüning 360, Jardim Santos Dumont, Paranavaí, PR 87706-490, Brazil. E-mail: srstabille@ wnet.com.br

The relation between hyperglycemia and diabetic neuropathy has already been demonstrated in some studies. Among the theories proposed for its etiology the oxidative stress stands out. The performance of nitric oxide as a link between the metabolic and vascular neuropathogenic factors that triggers the diabetic neuropathy has already been put forward. This study aimed to assess the quantification and measurements of the cell body profile area (CBPA) of NADPH-diaphorase reactive (NADPH-dp) myenteric neurons of the jejunum of diabetic rats (induced by streptozotocin) supplemented with Ascorbic Acid (AA). These changes in the myenteric neurons seem to be related to the gastrointestinal disturbances observed in diabetes mellitus (DM). Twenty male Wistar rats (Rattus norvegicus) were distributed in 4 groups $(n=5)$ : controls $(C)$, control supplemented (CS), diabetic (D), and diabetic suplemented (DS). DM was induced by estreptozotocin (50mg/ $\mathrm{kg}$ body wt). One week after the induction and confirmation of the DM (glycemia exam), animals of the groups CS and DS received $50 \mathrm{mg}$ of AA three times a week by gavage. After 90 days of experiment, the animals were anesthetized with lethal thiopental dose $(40 \mathrm{mg} / \mathrm{kg})$ and the collected jejunum processed for the histochemistry NADPH-diaphorase technique. Whole-mount preparations were obtained for quantitative and morphometric analysis of the myenteric neurons. A quantity of jejunum neurons in the Group D $(96 \pm 7.5)$ was not different $(P>0.05)$ from Group DS (116 \pm 8.08$), C(92 \pm 9.7)$, and CS $(81 \pm 5.4)$, but in Group DS the quantity was higher $(\mathrm{P}<0.05)$ than in Group $\mathrm{C}$ and $\mathrm{CS}$. The CBPA of neurons from Group D $\left(189.50 \pm 2.68 \mu \mathrm{m}^{2}\right)$ and DS $\left(195.92 \pm 3.75 \mu \mathrm{m}^{2}\right)$ were lower $(\mathrm{P}<0.05)$ than from Group C $\left(225.13 \pm 4.37 \mu \mathrm{m}^{2}\right)$ and CS $\left(210.23 \pm 3.15 \mu \mathrm{m}^{2}\right)$. The streptozotocin-induced DM did not change the jejunum-ileum area, the jejunum myenteric plexus space organization and the density of NADPH-dp neurons. The $50 \mathrm{~g} \mathrm{AA-supplementation,} \mathrm{three} \mathrm{times} \mathrm{a} \mathrm{week,}$ during 90 days, did not decrease hyperglycemia; however, it had a neuroprotective effect on the myenteric neurons, minimizing the increase on the CBPA of NADPH-dp neurons and increasing the amount of NADPD-dp neurons.
\end{abstract}

INDEX TERMS: Myenteric plexus, intestine, vitamin C, antioxidants, hyperglycemia.

\footnotetext{
${ }^{1}$ Received on October 29, 2007.

Accepted for publication on January 30, 2008.

2 Departamento de Ciências Biológicas, Universidade Paranaense (Unipar), Campus-Paranavaí, Av. Huberto Brüning 360, Jardim Santos Dumont, Paranavaí, PR 87706-490, Brazil. *Corresponding author: srstabille@wnet.com.br
}

\footnotetext{
${ }^{3}$ Departamento de Cirurgia, Faculdade de Medicina Veterinária e Zootecnia, Universidade de São Paulo, Av. Prof. Dr. Orlando Marques de Paiva 87, São Paulo, SP 05508-270, Brazil.

${ }^{4}$ Departamento de Morfologia, Centro de Ciências Biomédicas, Universidade Federal do Rio Grande do Norte, Cx. Postal 1524, Campus Universitário Lagoa Nova, Natal, RN 59072-970, Brazil.
} 
RESUMO.- [Avaliação dos neurônios NADPH-diaforase reativos do jejuno de raots diabéticos suplementados com ácido ascórbico.] A relação entre hiperglicemia e neuropatia diabética foi demonstrada em várias pesquisas. Entre as teorias propostas para sua etiologia destaca-se o estresse oxidativo. O papel do óxido nítrico como elo entre os fatores neuropatogênicos metabólico e vascular que ativam a neuropatia diabética tem sido ressaltado. Este estudo objetivou avaliar a quantificação e a morfometria da área do perfil do corpo celular (CBPA) de neurônios mioentéricos NADPH-diaforase reativos (NADPH-dp) do jejuno de ratos diabéticos e suplementados com Ácido Ascórbico (AA), uma vez que alterações nos neurônios mioentéricos parecem estar relacionadas aos distúrbios gastrointestinais observados no diabetes mellitus (DM). Vinte ratos machos da linhagem Wistar (Rattus norvergicus) foram distribuídos em 4 grupos $(n=5)$ : controle (C), controle suplementado (CS), diabético (D) e diabético suplementado (DS). O DM foi induzido através de injeção de estreptozootocina $(50 \mathrm{mg} / \mathrm{kg}$ de peso corporal). Uma semana depois da indução e confirmação do DM (glicemia), animais dos grupos CS e DS receberam, via gavagem, $50 \mathrm{mg}$ de AA três vezes por semana. Após 90 dias de período experimental, os animais foram anestesiados com dose letal de thiopental intravenosa $(40 \mathrm{mg} / \mathrm{kg})$ e o jejuno foi retirado e processado para a técnica histoquímica da NADPH-diaforase. Preparados de membrana foram obtidos para análises quantitativa e morfométrica dos neurônios mioentéricos. A quantidade de neurônios do jejuno do Grupo D $(96 \pm 7,5)$ não diferiu $(P>0,05)$ dos Grupos DS $(116 \pm 8,08)$, C $(92 \pm 9,7)$ e CS $(81 \pm 5,4)$, mas no Grupo DS o número de neurônios foi superior $(P<0,05)$ aos Grupos C e CS. A CBPA de neurônios do Grupo D $\left(189,50 \pm 2,68 \mu m^{2}\right)$ e DS $\left(195,92 \pm 3,75 \mu \mathrm{m}^{2}\right)$ foi menor $(P<0,05)$ do que a dos Grupos C $\left(225,13 \pm 4,37 \mu \mathrm{m}^{2}\right)$ e CS $\left(210,23 \pm 3,15 \mu \mathrm{m}^{2}\right)$. O DM induzido por estreptozootocina não alterou a área do jejuno-íleo, a organização espacial do plexo mioentérico e a densidade de neurônios de NADPH-dp do jejuno. A suplementação de $50 \mathrm{mg}$ de $A \mathrm{~A}$, três vezes por semana, durante 90 dias, não diminuiu a hiperglicemia, porém teve efeito neuroprotetor nos neurônios mioentéricos, minimizando o aumento na CBPA dos neurônios NADPHdp e aumentando a quantidade de neurônios reativos a NADPD-diaforase.

TERMOS DE INDEXAÇÃO: Plexo mioentérico, intestino; vitamina $\mathrm{C}$, antioxidantes, hiperglicemia.

\section{INTRODUCTION}

Diabetes mellitus (DM) affects animal and human beings and is a multiple etiology disease. Its main manifestations are due to disturbances in the metabolism of carbohydrates, fats and proteins associated to an absolute or relative deficiency in the insulin secretion by the pancreas beta cells. This deficiency is responsible for the chronic-degenerative complications along with vascular and nervous compromising manifested as macro and micro-angiopathies and neuropathies (Crawford \& Cotran 1996). In animals, as dogs and cats, the DM can occur at older ages mainly. Obesity and castration, besides age, are also risk factors for the appearance of DM in cats (Hoenig 2002).

The autonomic neuropathy is one among the several neuropathies that arise in the DM in gastrointestinal level. It leads to changes in the motor, sensorial and reflexive activities (Clarke et al. 1979) in form of diarrhea and constipation (Clements \& Bell 1982), megacolon and gastrointestinal transit slowness (Iber et al. 1993), stasis, and gastric dilatation with reduction or increase of peristaltic contractions, as well as more serious gastric problems such as gastroparesis characterized by anorexy, loss of weight, nauseas and vomits (Katz \& Spiro 1966, Clements \& Bell 1982).

Alterations in myenteric plexus are involved in the gastrointestinal abnormalities seen in the autonomic diabetic neuropathy. Studies have shown a decrease in the neuronal activity and the development of chromatolysis followed by degenerative changes (Monckton \& Pehowich $1980)$. There is also a reduction in neuron number, within short or long time, in the stomach (Fregonesi et al. 2001), duodenum (Buttow et al. 1997), ileum (Hernandes et al. 2000), caecum (Zanoni et al. 1997), and proximal colon (Romano et al. 1996, Furlan et al. 2002). Alterations in the neurotransmitters levels have also been observed (Balmann \& Conlon 1985, Belai \& Burnstock 1990), suggesting neuropathy due to DM which does not affect the myenteric neurons with the same intensity and extension, with a possible reduction of some neurotransmitters in some neurons, but not in others (Vinson et al. 1989, Baynes 1991).

The relationship between hyperglycemia and diabetic neuropathy has already been proven in some studies. The oxidative stress stands out among the theories proposed for its etiology (Giuliano et al. 1996, Afzaal et al. 2002). The oxidative stress in this neuropathy and in other DM complications is intensified by reduction in enzyme levels that participate in the antioxidant defense system (Parthiban et al. 1995, Obrosova et al. 2002), and also by reduction in antioxidant levels such as ascorbic acid (Young et al. 1992), glutathione and vitamin E (Lee \& Chung 1999).

Another potential mechanism for the rise of the oxidative stress in the DM is the disproportionate increase in the formation of free radicals due to glucose oxidation, nonenzymic glycation of proteins and subsequent oxidative degradation of the glycate proteins (Maritim et al. 2003), and changes in the polyol pathway activity (Baynes 1991, Ksiazek \& Wisniewska 2001, Davison et al. 2002).

The hyperglycemia activates the aldose reductase and sorbitol dehydrogenase, which are enzymes of the polyol pathway that catalyzes the conversion of glucose into sorbitol and fructose, respectively. Since the fructose and phospho-fructose have a restraining effect on the functional 
activity, and since sorbitol and fructose do not spread out easily along the plasmatic membrane, a gradual accumulation of sorbitol and fructose inside the nervous fibers takes place (Silva \& Teixeira 1999). The consequences of this accumulation are: 1 ) increase of the intracellular osmolarity, with formation of edema, neuronal injury and reduction of the nerve conduction (Hosking et al. 1978); 2) reduction in the content of myoinisitol, resulting in a decrease in the phosphoinositide metabolism and less activity of diacylglycerol, protein kinase $\mathrm{C}$ and $\mathrm{Na}+\mathrm{K}+$ ATPase (Crawford \& Cotran 1996), leading to an axo-glial disjunction and damaging the fiber, which may be the first structural abnormality of the diabetic neuropathy; and 3 ) reduction of the glutathione levels, both the glutathione reductase and aldose reductase (Cameron et al. 1993).

The neurons that liberate nitric oxide (NO) play a crucial inhibiting role in the motility control of the gastrointestinal tube (Jarvinen et al. 1999). Some authors have already proposed the $\mathrm{NO}$ action as the link between the metabolic and vascular neuropathogenic factors that triggers the diabetic neuropathy (Stevens et al. 1995). NO is produced when the L-arginine is reduced to L-citruline by the action of the enzyme nitric oxide synthase (NOS) (Olsson \& Holmgren 2001). The NOS enzyme is used to stain neurons by reducing the nitroblue tetrazolium in the presence of beta-nicotinemide adenine dinucleotide phosphate reduced (NADPH-reduced), which indicates that the histochemical NADPH-diaphorase can be used as an NO marker (Santer 1994).

Quantitative changes in the nitrergic neurons of the myenteric plexus and a reduction in the NOS activity in diabetic animals have been reported (Wrzos et al. 1997, Spangéus et al. 2000, Watkins et al. 2000), reinforcing the observation of a myenteric plexus compromising due to the autonomic diabetic neuropathy. Multiple therapeutic strategies have shown that the antioxidant treatments can prevent or revert the peripheral nervous dysfunction in streptozotocin-induced-diabetic rats (Cameron et al. 1993, Cameron \& Cotter 1999). The ascorbic acid supplementation reduces the capillary fragility and the cellular sorbitol concentration (Cunningham et al. 1998), suggesting a neuroprotective effect of this substance.

The aim of this study was to quantify and assess the morphometry of the NADPH-diaphorase stained neuron population of the jejunum myenteric plexus of streptozotocin-induced diabetic rats supplemented with $A A$, taking into consideration the neuropathy relevance as one of the chronic-degenerative complications due to DM.

\section{MATERIALS AND METHODS}

Twenty male rats (Rattus norvegicus) of Wistar lineage with 3 months of age, supplied by the Central Vivarium of the University of São Paulo, were used.The animals were distributed in four groups with five animals each $(n=5)$ as follows: Group D (diabetic); Group C (normoglycemic control); Group DS (diabetic AA-supplemented), and Group CS (AA-supplemented normoglycemic control).
The animals were housed in separate polypropylene cages, at room temperature $\left(24 \pm 2^{\circ} \mathrm{C}\right)$ and controlled photoperiod (12 hours dark/light cycle) with access to food and water ad libitum. During the 90-days experiment period, the animals were weighed once a week.

This study was done within the guidelines of the COBEA (Brazilian College for Animal Experimentation) and was approved by the CEPEEA (Institutional Committee for Ethics in Animal Experimentation) from Unipar.

\section{Streptozotocin-induced diabetes mellitus and ascorbic acid supplementation (AA)}

After a previous 14 hours fasting, each animal of groups D and DS received a single dose of streptozotocin $(50 \mathrm{mg} / \mathrm{kg}$ of body weight) dissolved in sodium citrate buffer $10 \mathrm{~mm}, \mathrm{pH} 4.5$, through intravenous injection (penile vein). The animals from Group C and CS received the same dose of $10 \mathrm{~mm}$ sodium citrate buffer. One week after the induction and confirmation of diabetes onset (blood glucose exams), every animal from Group CS and DS received 50mg of AA (through gavage), three times a week, during 90 days.

\section{Obtaining intestinal segments}

At the end of the experimental period, after fasting for 12 hours, the animals were put down with a lethal dose of anaesthetic (Thiopental Abbout ${ }^{\circledR} 40 \mathrm{mg} / \mathrm{kg}$ ) given by intravenous injection. Blood was collected through cardiac punction in order to measure the glucose levels (Bergmeyr \& Bernet 1974). A laparotomy was then carried out to retrieve the jejunum.

\section{The jejunum-ileum area $\left(\mathrm{mm}^{2}\right)$}

The length and diameter $(\mathrm{mm})$ of the jejunum-ileum were measured. The total area was estimated in the animals from Group C, D, DS and CS. This procedure was used to show possible changes in the intestinal area caused by the DM that could hinder the neuronal quantification data.

\section{NADPH-diaphorase histochemical technique (Scherer- Singler et al. 1983)}

The collected jejunums were washed and filled with phosphate buffer (PB, pH 7.4), had their extremities tied with suture thread, fixed in $4 \%$ paraformaldehyde (Merck, Darmstadt, Germany) prepared in phosphate buffer $0.1 \mathrm{M}(\mathrm{PB}, \mathrm{pH} 7.4)$ for $30 \mathrm{~min}$, immersed in $0.3 \%$ Triton $\mathrm{X}-100 \circledast$ (Sigma, St. Louis, USA) dissolved in saline phosphate buffer (PBS, pH 7.4) for $10 \mathrm{~min}$ and then washed 10 times (10 min each wash) in PBS The jejunums later. The segments were washed twice in sodium phosphate buffer solution (SPB) (10 minutes each), and fixed in parafolmadeyde $4 \%$ for 30 minutes and followed by permeabilization in SPB with $0.3 \%$ Triton $\mathrm{X}-100$ dissolved in sodium phosphate buffer $(\mathrm{pH} 7,3)$ for 10 minutes and then washed twice in SPB for 10 minutes each. Subsequently, jejunums were incubated in a broth containing $50 \mathrm{mg}$ of Nitro Blue Tetrazolium (Sigma $\left.{ }^{\circledR}\right), 100 \mathrm{mg}$ of b-NADPH (Sigma®) and $0.3 \%$ Triton $\mathrm{X}-100$ in buffered Tris $-\mathrm{HCl}$ drain plug $(0.1 \mathrm{M} \mathrm{pH}$ 7,6).

The histochemical reaction was controlled visually with the aid of stereomicroscope and lasted for 100 minutes. After incubation the samples were opened at the mesenteric attachment and washed three times in PBS for five minutes, were opened by cutting to sutures at their extremities and then immersed in $4 \%$ paraformaldehyde solution. 


\section{Obtaining the membrane whole-mounts}

The jejunum was sectioned throughout the extension of the mesenteric edge and microdissected in a glass plate, with the aid of micro clamp and micro shears, under the stereomicroscope with transillumination to remove the mucosal layer and the submucosal screen, preserving the muscular and serosal layers. Each membrane whole-mount was dehydrated in a ascending series of alcohols (90-100\%) and clarified by three consecutive immersions in xylol, then placed between glass blade with Permount resin. The membrane whole-mount preparations were used for the quantification and morphometric analyses of the cellular body profile area of myenteric neurons.

\section{Quantification of NADPH-diaphorase positive neurons}

The jejunum membrane whole-mount was visualized by light microscope in order to perform the neuronal quantification area $\left(\mathrm{mm}^{2}\right)$. The image seen in the microscope was captured by a high resolution digital camera and transferred to a computer.

The neurons were quantified by means of a system test adapted to each membrane whole-mount consisting of 60 fields. Based on the width and length of the membrane whole-mount preparations, the 60 fields were distributed as ten columns with 6 lines each, sampling all regions (mesenteric, intermediate and anti-mesenteric). As the jejunum varies in its circumference, a rectangular sampling test system with fixed dimensions could not be adjusted for this material. Therefore, we needed to make an adjustment for each column inside the membrane wholemount preparation. However, the column points were adjusted so that they kept the same distance between themselves.

Measurement of the cell body profile area of NADPHdiaphorase positive neurons

The measurement of the cell body profile area (CBPA) of $\mathrm{NADPH}$-diaphorase positive (NADPH-dp) myenteric neurons was carried through image-analyses software (Image-Pro-Plus 3.0.1). The images of the neurons captured for digital chamber for the quantification of the neuronal density had been used. The CBPA (in im ${ }^{2}$ ) of all the neurons quantified previously in the membrane whole-mount preparations of each animal for group had been measured. The neurons had been grouped by class intervals of $100 \mu \mathrm{m}^{2}$.

\section{Statistical analysis}

The data related to the neuronal quantification were analyzed by the Kruskal-Wallis test to compare the groups. As for the data concerning the animals' weight, blood glucose levels, jejunum-ileum area and the neurons CBPA of different groups were compared by the test of Tukey. The adopted significance level for all groups was $P<0.05$. All the results were expressed as mean \pm standard error

\section{RESULTS}

The animals from all groups gained weight (Table 1) throughout the 90-days experiment period. However, animals from Group D and DS gained less weigh (although not in a significant way $P>0.05$ ) when compared to animals from Group C and CS (Table 1).

The blood glucose dosage performed at the beginning and at the end of the experiment confirmed the diabetes presence in the animals from groups $D$ and DS, which showed higher blood glucose concentration $(P>0.05)$ than
Table 1. Body weight at 90 -days and at 180 -days of age of rats from groups C (normoglycemic), CS (normoglycemic AA-supplemented), D (diabetic) e DS (diabetic AAsupplemented)

\begin{tabular}{ccc}
\hline Group & Initial weight $(\mathrm{g})$ & Final weight $(\mathrm{g})$ \\
\hline $\mathrm{C}(\mathrm{n}=5)$ & $295^{\mathrm{a}} \pm 15.81$ & $430.3^{\mathrm{b}} \pm 27.4$ \\
CS $(\mathrm{n}=5)$ & $301,5^{\mathrm{a}} \pm 2.02$ & $430.4^{\mathrm{b}} \pm 20.39$ \\
$D(\mathrm{n}=5)$ & $283,3^{\mathrm{a}} \pm 11.24$ & $395.5^{\mathrm{b}} \pm 31.2$ \\
DS $(\mathrm{n}=5)$ & $314^{\mathrm{a}} \pm 12.25$ & $367.5^{\mathrm{b}} \pm 59.25$
\end{tabular}

Means followed by different letters in the same line and column are different $(P<0.05)$ by the test of Tukey

Table 2. Initial and final glycemia and jejunum-ileum surface area $\left(\mathrm{mm}^{2}\right)$ means of rats from groups C (normoglycemic), CS (normoglycemic AA-supplemented), D (diabetic) and DS (diabetic AA-supplemented)

\begin{tabular}{ccrc}
\hline Group & $\begin{array}{c}\text { Initial glycemia } \\
\left(\text { mg. }^{-1}\right)\end{array}$ & $\begin{array}{r}\text { Final glycemia } \\
\left(\text { mg. }^{-1}\right)\end{array}$ & Jejunum-ileum area \\
\hline C $(n=5)$ & $101.3^{\mathrm{a}} \pm 5.26$ & $101.3^{\mathrm{a}} \pm 3.54$ & $1128 \pm 35.91^{\mathrm{a}}$ \\
CS $(\mathrm{n}=5)$ & $97.25^{\mathrm{a}} \pm 4.73$ & $95^{\mathrm{a}} \pm 2.85$ & $1232 \pm 31.27^{\mathrm{a}}$ \\
D $(\mathrm{n}=5)$ & $387^{\mathrm{b}} \pm 16.97$ & $446.5^{\mathrm{b}} \pm 5.33$ & $1218 \pm 30.89^{\mathrm{a}}$ \\
DS $(\mathrm{n}=5)$ & $395.5^{\mathrm{b}} \pm 4.62$ & $436.5^{\mathrm{b}} \pm 1.37$ & $1198 \pm 41.04^{\mathrm{a}}$ \\
\cline { 1 - 2 }
\end{tabular}

Means followed by different letters in the same line and column are different $(\mathrm{P}<0.05)$ by the test of Tukey.

Table 3. Means and standard error of the average density of NADPH-dp myenteric neurons in $13.26 \mathrm{~mm}^{2}$ the jejunum and the cell body profile area (CBPA) in animals from Group C (normoglycemic), CS (normoglycemics AA-supplemented), D (diabetic), and DS (diabetic AAsupplemented)

\begin{tabular}{ccc}
\hline Group & Neuronal density & CBPA $\left(\mathrm{mm}^{2}\right)$ \\
\hline$C(n=5)$ & $92^{a b_{ \pm}}+9.7$ & $225.13^{\mathrm{a}_{ \pm}} \pm .37$ \\
CS $(n=5)$ & $81^{\mathrm{a}} \pm 5.4$ & $210.23^{\mathrm{b}} \pm 3.15$ \\
$D(n=5)$ & $95^{a b_{ \pm}}+7.5$ & $189.50^{\mathrm{c}} \pm 2.68$ \\
$D S(n=5)$ & $116^{\mathrm{b}} \pm 8.08$ & $195.92^{\mathrm{c}} \pm 3.75$
\end{tabular}

Means followed by different letters in the same column are different $(\mathrm{P}<0.05)$ by the test of Kruskal-Wallis for the neuronal density and by the test of Tukey for the cell body profile area.

those in groups $\mathrm{C}$ and $\mathrm{CS}$. There was no difference $(\mathrm{P}>0.05)$ between the glucose values of Group D and DA (Table 2).

The jejunum-ileum surface area was similar among Group C, CS, D and DS. The DM and the AA supplementation did alter this parameter (Table 2).

The myenteric plexus presented NADPH-dp inside the ganglions crossconnected by fiber bundles in the jejunum whole-mounts of animals from all groups (Fig.1). The quantification of NADPH-dp neurons was carried out through a test system in 60 microscopic fields per membrane wholemount. The corresponding area to the 60 fields was 13.26 $\mathrm{mm}^{2}$. The neuronal density of Group D $(95 \pm 7.5)$ was not different $(P>0.05)$ from the other groups and was higher $(P<0.05)$ in the jejunum of Group DS $(116 \pm 8.08)$ than in Group C $(92 \pm 9.7)$ and CS $(81 \pm 5.4)$ (Table 3).

The CBPA in the neurons of Group $C$ ranged from 58.68 to $471.72 \mu \mathrm{m}^{2}$; from 82.71 to $423.78 \mu \mathrm{m}^{2}$ in Group CS; from 


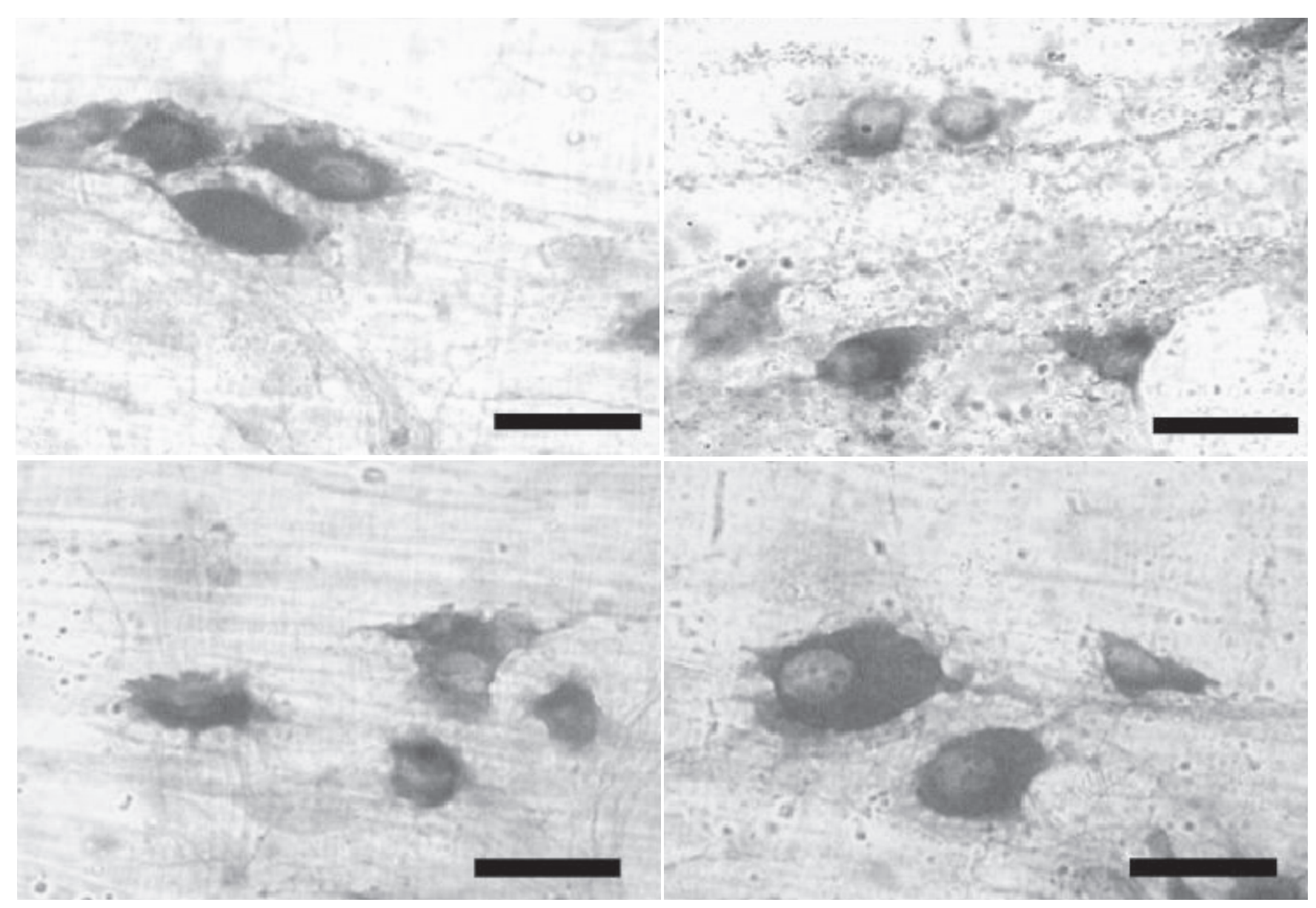

Fig.1. Ganglions from the jejunum myenteric plexus showing NADPH-diaphorase reactive neurons. 400x. Bar: 50 4 m.

Table 4. Relative frequency (\%) of NADPH-dp myenteric neurons from the jejunum of rats from Group $C$ (normoglycemic), CS (normoglycemic AA-supplemented), D (diabetic), and DS (diabetic AA-supplemented) according to the cell body profile area at class intervals of $100 \mu \mathrm{m}^{2}$

\begin{tabular}{ccccc}
\hline Area $\mu \mathrm{m}^{2}$ & \multicolumn{4}{c}{ Relative frequency of neurons (\%) } \\
\cline { 2 - 5 } & $\begin{array}{c}\text { Group C } \\
(\mathrm{n}=5)\end{array}$ & $\begin{array}{c}\text { Group D } \\
(\mathrm{n}=5)\end{array}$ & $\begin{array}{c}\text { Group CS } \\
(\mathrm{n}=5)\end{array}$ & $\begin{array}{c}\text { Group DS } \\
(\mathrm{n}=5)\end{array}$ \\
\hline$<100$ & 4 & 3 & 2 & 9 \\
$100 \vdash 3 / 4200$ & 43 & 59 & 44 & 46 \\
$200 \vdash 3 / 4300$ & 32 & 33 & 45 & 34 \\
$300 \vdash 3 / 4400$ & 16 & 5 & 8 & 10 \\
$>400$ & 5 & - & 1 & 1 \\
Total & 100 & 100 & 100 & 100
\end{tabular}

77.43 to $360.03 \mu \mathrm{m}^{2}$ in Group D and from 58.68 to $440.76 \mu \mathrm{m}^{2}$ in Group DS. The CBPA of neurons from Group D $(189.50 \pm 2.68)$ and DS $(195.92 \pm 3.75)$ were lower $(\mathrm{P}<0.05)$ than Group C $\left(225.13 \pm 4.37 \mu \mathrm{m}^{2}\right)$ and CS $\left(210.23 \pm 3.15 \mu \mathrm{m}^{2}\right)$ (Table 3).

The relative frequency of neurons of each group according to class intervals regarding the dimensions of the CBPA can be seen on Table 4. In all groups there was a prevalence of neurons with a cell body profile area in the class interval between 100 and $300 \mu \mathrm{m}^{2}$ (Fig 2).

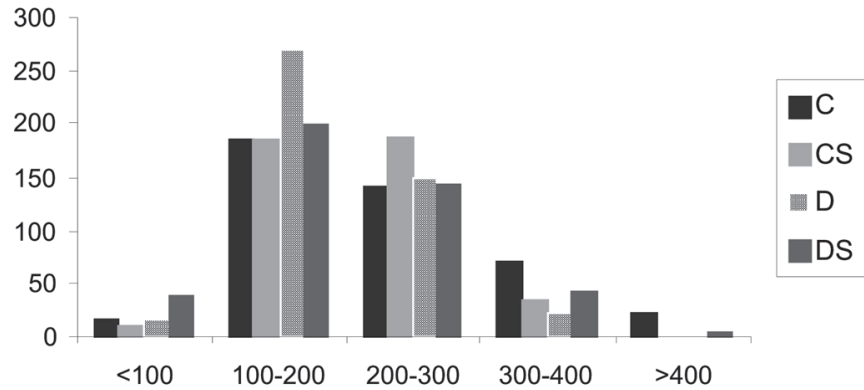

Fig.2. Frequency histogram of HADPH-dp myenteric neurons from Group C (normoglycemic), CS (normoglycemic AAsupplemented), D (diabetic), and DS (diabetic AAsupplemented) according a class interval of the cell body profile area in $\mu \mathrm{m}^{2}$.

\section{DISCUSSION}

The streptozotocin injection with a dose of $50 \mathrm{mg} / \mathrm{kg}$ of body weight was efficient in the induction of diabetes in the animals from Group D and DS. At the end of the experiment that lasted 90 days, the glycemia in Group D $\left(446.5 \pm 5.33 \mathrm{mg}^{-\mathrm{dl}^{-1}}\right)$ and in Group DS $\left(436.5 \pm 1.37 \mathrm{mg}-\mathrm{dl}{ }^{1}\right)$ was higher $(P<0.05)$ than those in Group C $(101.3 \pm 3.54 \mathrm{mg}$ $\left.\mathrm{dl}^{-1}\right)$, and CS $\left(95 \pm 2.85 \mathrm{mg}^{-\mathrm{dl}^{-1}}\right)$. This result was expected since the streptozotocin given in doses higher than $25 \mathrm{mg} /$ $\mathrm{kg}$ is diabetogenic (Ar'rajab \& Ahrén 1993) and has been 
used on diabetes research (Szkudelski 2001). The AAsupplementation of diabetic and normoglycemic animals did not interfere in the glucose blood concentration, since the glycemia concentrations in the animals from group DS were similar to those from Group D, showing the little effect of the AA on the glycemia concentration as described by Young et al. (1992).

At the beginning of the experiment, there was no difference $(P>0.05)$ in the body weight of animals from Group C, CS, D, and DS. These results were kept until the end of the experiment. The weight gain in Group D (112.2g) and DS (53.5g) was lower than those in Group C $(135.3 \mathrm{~g})$ and $C S(128.9 \mathrm{~g})$, although they were not significantly $(P>0,05)$ differing from the results of other experiments. In rats, Thulesen et al. (1997) reported that the diabetic animals lost $16 \%$ of weight when compared to normoglycemic animals. Lindsay et al. (1998) observed a loss of $25.6 \%$ in the weight of diabetic rats and Furlan et al. (2002) observed a loss of $19.6 \%$ of body weight. The difference observed in the results and those mentioned in literature may be due to the duration of the experiment that, in this study, was 90 days while in the others was 120 days or one week. It was also verified that the AA supplementation did not interfere in the weight gain among the groups.

The oxidative stress intensification in the DM has already been reported (Ksiazek \& Wisniwska 2001, Davison et al. 2002). According to Feldman (2003), the accumulation of superoxides, activity increase of the polyol pathway, accumulation of AGEs products (advanced glycation end), change in the activity of the protein kinase$\mathrm{C}$ and in the hexosamine pathway flow trigger a gradual cellular dysfunction in diabetes. Each pathway is altered in a direct or indirect consequence of the overproduction of superoxides by the electron transport chain in the mitochondria, mediated by the hyperglycemia. Thus, it is expected that the inhibition of the superoxide production or the euglycemia may restore the metabolic and vascular balance and block the onset and the progression of complications in the organism.

The use of antioxidants and inhibitor of aldosereductase (essential for the polyol pathway) has been investigated with intention to minimize or prevent the deleterious effect of DM. The AA is an antioxidant (Levine 1986) and an inhibitor of the aldose-reductase (Will \& Byers 1996), but its concentration in diabetic rats and in diabetic human beings is low (McLennam et al. 1988).

When the blood glucose increases there is a reduction in the amount of AA in the blood, although the opposite is not true (Young et al. 1992). In this experiment, the animals received $50 \mathrm{mg}$ of $A A$, through gavage, three times a week, an amount one time higher than the amount of AA synthesized daily by rats (Young et al. 1992). However, this higher dosage did not hinder the glycemia increase in animals from Group DS.

The jejunum-ileum area of all animals was measured to assess possible changes in the muscular tonus and, as observed in caecum (Zanoni et al. 1997) and in the stomach (Clebis et al. 2004) of diabetic and normoglycemic rats, with no significant differences $(P>0.05)$ between Group C $\left(1128 \pm 35.91 \mathrm{~mm}^{2}\right)$, D $\left(1218 \pm 30.89 \mathrm{~mm}^{2}\right)$, CS $\left(1232 \pm 31.27 \mathrm{~mm}^{2}\right)$, and DS $\left(1198 \pm 41.04 \mathrm{~mm}^{2}\right)$. These results indicated that the jejunum-ileum area was neither affected by the DM nor by the AA-supplementation.

According to Irwin (1931), the myenteric neurons in the muscular layer of the gastrointestinal tube are gathered in ganglions crossconnected by nerve fibers forming, thus, a ganglionated mesh or net. A similar display of the myenteric plexus was observed in the jejunum membrane whole-mount in all groups, indicating that the DM and the AA supplementation did not modify the space display of jejunum myenteric plexus.

In order to assess the effect of the DM and the AA supplementation on the NADPH-dp myenteric neurons, it was quantified the neurons in a total area of $13.26 \mathrm{~mm}^{2}$ of the jejunum per animal, and measured the cell body profile area.

A quantity of jejunum neurons in the Group D $(96 \pm 7.5)$ was not different $(P>0.05)$ from Group DS (116 \pm 8.08$)$, C $(92 \pm 9.7)$, and CS $(81 \pm 5.4)$, but in Group DS the quantity was higher $(P<0.05)$ than Group $C$ and $C S$, proving that the diabetes did not interfere in the quantity of NADPH-dp neurons of diabetic rats but that the AA supplementation allowed the evidenciation of a higher number of neurons reactive to the enzyme NADPH-diaphorase in a hyperglycemia condition. A decrease in the number of neurons reactive to the NADH-diaphorase and of neurons stained by the immunomarker myosin $\mathrm{V}$ or evidenced by the methylene blue has been observed in the duodenum (Büttow \& Miranda-Neto 1997), in the large intestine as a whole (Hernandes et al. 2000), in the caecum (Zanoni et al. 1997) and in the proximal colon (Furlan et al. 2002, Romano et al. 1996) in the diabetes mellitus. However, there were reports of an increase in the quantity of NADPH$\mathrm{dp}$ myenteric neurons in the stomach pyloric area (Fregonesi et al. 2005) and no significant change in the quantity of NADPH-dp neurons in the ileum was observed by Zanonni et al. (2003). Similarly, Wrzos et al. (1997) verified that the nitric oxid synthase expression in the duodenum, ileum and colon of diabetic rats did not differ from those observed in the controls.

The DM interfered on the CBPA decreasing the neuron CBPA size since there was a difference $(P<0.05)$ between Group D $\left(189.50 \pm 2.68 \mu \mathrm{m}^{2}\right)$ and DS $\left(195.92 \pm 3.75 \mu \mathrm{m}^{2}\right)$ when compared to Groups C $\left(225.13 \pm 4.37 \mu \mathrm{m}^{2}\right)$ and CS $\left(210.23 \pm 3.15 \mu \mathrm{m}^{2}\right)$, and although not significant $(P>0.05)$ this decrease on the neurons CBPA size was less sharp in Group DS. Fregonesi et al. (2005) obtained different results in the pyloric region of diabetic rats, in which the NADPH-dp neurons had a higher CBPA than the normoglycemic group, the same occurring in the in the ileum (Zanoni et al. 2003) and in the other stomach areas (Fregonesi et al. 2002, 2005). However, the neurons size in Group DS $\left(195.92 \pm 3.75 \mu \mathrm{m}^{2}\right)$ and CS (186.87 \pm 
$\left.16.88 \mu \mathrm{m}^{2}\right)$ was significantly $(P<0.05)$ smaller than those from Group D and C, respectively. Thus, it seems that after a certain period of the supplementation, the AA antioxidant action, or even the inhibiting action of the enzyme aldose-reductase, might have contributed to diminish the oxidative stress in the diabetic rats (Group DS) and the natural oxidative stress in the normoglycemic rats (Group CS). It might have also hindered the sorbitol accumulation that leads to neuronal edema, allowed the nitrergic neurons to express NOS in a smaller concentration and, as a result of the smaller NOS production, decreasing its cellular activity, making the neuron a smaller cell or, even, avoiding the edema and the neuronal death. It is worth to notice that $62 \%$ of the neurons from Group D and $55 \%$ of the neurons from Group DS had a CBPA lower than $200 \mathrm{~mm}^{2}$. In Group C and CS, $53 \%$ and $54 \%$ of the neurons, respectively, presented a cell profile area higher than $200 \mathrm{~mm}^{2}$. A similar effect was observed by Zanoni et al. (2003) in the nitrergic neurons of myenteric plexus and in the immunoreactive neurons for the reactive vasointestinal peptide of submucous plexus of the ileum of rats (Zanoni et al. 2002).

As the NO is an inhibitory neurotransmitter, its increase could intensify the muscular relaxation of the digestive tube causing a reduction in the emptying of segments such as the stomach (Fregonesi et al. 2005) and, when in reduced concentration it could, obviously, promote the opposite, that is, to diminish the relaxation of the gastrointestinal smooth muscles, speeding up the transit and favoring the diarrhea.

The DM seems to inhibit the NO production in the jejunum myenteric neurons. This effect is compensated in the AA supplementation that promoted the increase in the amount of neurons that express $\mathrm{NO}$ in the diabetes.

Summing up, the treatment with AA with a $50 \mathrm{mg}$ dose, three times a week, seems to interfere with the density of nitrergic neurons increasing the quantity of these neurons in diabetic animals (Group DS) and hindering the increase of the cell body profile that could speed up or intensify the neuronal loss in animals with DM, since the supplemented animals (Group CS and DS) presented a cellular profile lower than the normoglycemic (Group C).

\section{CONCLUSIONS}

The results of this study led to reach the following conclusions:

The streptozotocin-induced DM in rats with a single dose of $50 \mathrm{mg} / \mathrm{kg}$ of body weight and kept for 90 days from the 90-days of age did not change the jejunum-ileum area, the muscular layer thickness, the space organization of the myenteric plexus in the jejunum and the NADPH-dp neurons density;

The $50 \mathrm{~g} \mathrm{AA}$-supplementation, three times a week, via gavage, during 90 days, did not decrease the hyperglycaemia, but had a neuroprotector effect on the myenteric neurons, minimizing the increase on cell body profile area of NADPH-dp neurons and increasing the quantity of NADPH-dp neurons.
Acknowledgements.- The authors thank Dr. Haroldo Garcia de Faria for his help with the statistical analysis and Unipar by PIBIC (Scientific initiation program) and financial support.

\section{REFERENCES}

Afzaal S., Sing M. \& Saleem I. 2002. Aetiopathogenesis and management of neuropathy. J. Assoc. Physicians India 50(5):707711.

Ar'rajab A. \& Ahrén B. 1993. Long-term diabetogenic effect of streptozotocin in rats. Pancreas 8(1):50-57.

Ballmann M. \& Conlon J.M. 1985. Changes in the somatostatin, substance $P$ and vasoative intestinal polypeptide content of the gastrointestinal tract following streptozotocin-induced diabetes in the rat. Diabetologia 28:335-358.

Baynes J.W. 1991. Role of oxidative stress in development of complications in diabetes. Diabetes 40:405-412.

Belai A. \& Burnstock G. 1990. Changes in adrenergic and peptidergic nerves in the submucous plexus of streptzotocin-diabetic rat ileum. Gastroenterology 98:1427-1436.

Bergmeyer M.V. \& Bernet E. 1974. Determination of glucose with glucoseoxidase and peroxidase, p.1204-1212. In: Bergmeyer H.U. (ed.), Methods of Enzimatic Analysis. Chemie-Academic Press, New York.

Buttow N.C., Miranda-Neto M.H. \& Bazotte R.B. 1997. Morphological and quantitative study of the myenteric plexus of the duodenum of streptozotocin-induced diabetic rats. Arq. Gastroenterol. 34:34-42.

Cameron N.E., Cotter M.A. \& Maxfield E.K. 1993. Anti-oxidant treatment prevents the development of peripherical nerve disfunction in streptozotocin-diabetic rats. Diabetologia 36(4):299-304.

Cameron N.E. \& Cotter M.A. 1999. Effects of antioxidants on nerve and vascular dysfunction in experimental diabetes. Diabetes Res. Clin. Pract. 45(2-3):137-146.

Clarke B.F., Ewing D.J. \& Campbell I.W. 1979. Diabetic autonomic neuropathy. Diabetologia 17:195-212.

Clebis N.K., Stabille S.R., Seyfert C.E., Gagliardo K.M., Mari R.M., Guimarães J.P., Molinari S.L., Miranda-Neto M.H., Zanoni J.N., Rossi R.M., Janeiro V. \& Souza R.R. 2004. Avaliação quantitativa e morfométrica dos neurônios mioentéricos da região aglandular do estômago de ratos com diabetes mellitus induzido por estrepto-zootocina e suplementados com ácido ascórbico. Arq. Ciênc. Saúde Unipar 8(2):87-93.

Clements R.S. \& Bell D.S.H. 1982. Diabetic neuropathy: peripheral and autonomic syndromes. Diabetic Neuropathy 71:50-67.

Crawford J.M. \& Cotran R.S. 1996. Pâncreas, p.806-833. In: Cotran R.S., Kumar V., Robbins S.L. \& Schoen F.J. (ed.), Robbins' Patologia Estrutural e Funcional. $5^{\mathrm{a}}$ ed. Guanabara Koogan, Rio de Janeiro.

Cunningham J.J. 1998. The glucose/insulin system and vitamin C: implications in insulin-dependent diabetes mellitus. J. Am. Coll. Nutr. 17:105-108.

Davison G.W., George L., Jackson S.K., Yong I.S., Davies B., Bailey D.M., Peters J.R. \& Ashton T. 2002. Exercise, free radicals, and lipid peroxidation in type I diabetes mellitus. Free Radical Biology 33:154351.

Feldman E.L. 2001. Oxidative stress and diabetic neuropathy: a new understanding of an old problem. J. Clin. Invest.111:431-433.

Fregonese C.E.P.T., Miranda-Neto M.H., Molinari S.L. \& Zanoni J.N. 2001. Quantitative study of the myenteric plexus of the stomach of rats with streptozotocin-induced diabetes. Arq. Neuropsiquiatr. 59:5053.

Fregonesi C.E.P.T., Molinari S.L. \& Miranda-Neto M.H. 2002. Avaliação da população de neurônios mioentéricos nadph-diaforase positivos do corpo do estômago de ratos com diabetes crônico induzido pela estreptozootocina. Acta Scientiarum 26(1):107-112.

Fregonesi C.E.P.T., Molinari S.L., Alves A.M.P., Defani M.A. \& MirandaNeto M. H. 2005. Aspectos morfoquantitativos de neurônios mioenté- 
ricos nadph-diaforase postivios do estômago de ratos diabéticos. Arq. Ciênc. Saúde Unipar 9(3):155-159.

Furlan M.M.D.P., Molinari S.L. \& Miranda-Neto M.H. 2002. Morphoquantitative effects of acute diabetes on the myenteric neurons of the proximal colon of adult rats. Arq. Neuropsiquiatr. 60:576-581.

Giuliano D., Ceriello A. \& Paolisso G. 1996. Oxidative stress and diabetic vascular complications. Diabetes Care 9(3):257-267.

Hernandes L., Bazotte R.B., Gama P. \& Miranda-Neto M.H. 2000. Streptozotocin-induced diabetes duration is important to determine changes in the number and basophily of myenteric neurons. Arq. Neuropsiquiatr. 58(4):1035-1039.

Hoenin M. 2002. Comparative aspects of diabetes mellitus in dog and cats. Mol. Cell. Endocrinol. 197:221-229.

Hosking D.J., Bennet T. \& Hampton J.R. 1978. Diabetic autonomic neuropath. Diabetes 27:1043-1055.

Iber F.L., Parveen S., Vandrunen M., Sood K.B., Reza F., Serlovsky R. \& Reddy S. 1993. Relation of symptoms to impaired stomach, small bowel, and colon motility in long-standing diabetes. Digest. Dis. Sci. 38(1):45-50.

Irwin D.A. 1931. The anatomy of Auerbach's plexus. Am. J. Anat. 49(1):141-165.

Jarvinen M.K., Wollmann W.J., Powrozek T.A., Schultz J.A. \& Powley T.L. 1999. Nitric oxide syntase-containing neurons in the myenteric plexus of the rat gastrointestinal tract: distribution and regional density. Anat. Embryol. 199:99-112.

Katz L.A. \& Spiro H.M. 1966. Gastrointestinal manifestations of diabetes. N. Engl. J. Med. 275(24):1350-1361.

Ksiazek K. \& Wisniewska J. 2001. The role of glucose and reactive oxygen species in the development of vascular complications of diabetes mellitus. Przegl Lek. 58:915-918.

Lee A.Y.W. \& Chung S.S.M. 1999. Contribuitions of polyol pathway to oxidative stress in diabetic cataract. FASEB Journal 13:23-30.

Levine M. 1986. New concepts in the biology and biochemistry of ascorbic acid. N. Engl. J. Med. 314:892-902.

Lindsay R.M., Jamieson N.S.D., Walker S.A., McGuigan C.C., Smith W. \& Baird J.D. 1998. Tissue ascorbic acid and polyol pathway metabolism in experimental diabetes. Diabetologia 41:516-523.

Maritim A.C., Sanders R.A. \& Watkins J.B. 2003. Diabetes, oxidative stress, and antioxidants: A review. J. Biochem. Mol Toxicol. 17(1):24-38.

McLennan S., Yue D.K., Fisher E., Capogreco C., Heffernan S., Ross G.R. \& Turtle J.R. 1988. Deficiency of ascorbic acid in experimental diabetes. Diabetes 37:359-361.

Monckton G. \& Pehowich E. 1980. Autonomic neuropathy in the streptozotocin diabetic rat. Can. J. Neurol. Sci. 7:142-153.

Obrosova I.G., Van Huysen C., Fathallah L., Cao X., Greene D.A. \& Stevens M.J. 2002. An aldose reductase inhibitor reverses early diabetes-induced changes in perpherical nerve function, metabolism, and antioxidative defense. FASEB Journal 16:123-25.

Olsson C. \& Holmgren S. 2001. The control of gut motility. Comp. Biochem. Physiol. A 128(3):481-503.

Parthiban A., Vijayalingam S., Shanmugasundaram K.R. \& Mohan R. 1995. Oxidative stress and the development of diabetic complications- antioxidants and lipid peroxidation in erythrocytes and cell membrane. Cell Biol. Intern. 19:987-993.

Romano E.B., Miranda-Neto M.H. \& Cardoso R.C. 1996. Preliminary investigation about the effects of streptozotocin-induced chronic diabetes on the nerve cell number and size of myenteric ganglia in rat colon. Revta. Chil. Anat. 14:139-145.

Santer R.M. 1994. Survival of the population of NADPH-diaphorase stained myenteric neurons in the small intestine of aged rats. J. Auton. Nerv. Syst. 49:115-121.

Scherer-Singler U., Vincent S.R., Kimura H. \& McGeer E.G. 1983. Demonstration of unique population of neurons with nadph-diaphorase histochemistry. J. Neurosci. Method. 9(3):229-234.

Silva C.B. \& Teixeira M.J. 1999. Neuropatia diabética. Revta Med. São Paulo 78:150-162.

Szkudelski T. 2001. The mechanism of alloxan and streptozotocin action in B cells of the rat pancreas. Physiol. Res. 50:536-546.

Spangéus A., Suhr O. \& El-Salhy M. 2000. Diabetic state affects the innervation of gut in an animal model of human type 1 diabetes. Histol. Histopathol. 15:739-744.

Stevens M.J., Feldman E.L. \& Greene D.A. 1995. The aetiology of diabetic neuropathy: the combined roles of metabolic and vascular defects. Diabetic Med. 12:566-579.

Thulesen J., Orkovic C., Holst J.J. \& Poulsen S.S. 1997. Short terminsulin treatment prevents the diabetogenic action of streptozotocin in rats. Endocrinology 138(1):62-68.

Vinson J.A., Staretz M.A., Bose P. \& Kassm H.M. 1989. In vitro and in vivo reduction of erythrocyte sorbitol by ascorbic acid. Diabetes 38:1036-1041.

Watkins C.C., Sawa A., Jaffrey S., Blaekshaw S., Barrow R.K., Snyder S.H. \& Ferris C. 2000. Insulin restores neuronal nitric oxide synthase expression and function that is lost in diabetic gastropathy. Journal of Clinical Investigation 106(3):373-384.

Will J.C. \& Byers T. 1996. Does diabetes mellitus increase the requirement for vitamin C? Nutr. Rev. 54:193-202.

Wrzos H.F., Cruz A., Polavarapu R., Shearer D. \& Ouyang A. 1997. Nitric oxide syntase (NOS) expression in the myenteric plexus of streptozotocin-diabetic rats. Digest. Dis. Sciences 42(10):2106-2110.

Young I.S., Torney J.J. \& Trimble E.R. 1992. The effect of ascobate supplementation on oxidative stress in the streptozotocin diabetic rat. Free Radical Biol. Med. 13:41-46.

Zanoni J.N., Miranda-Neto M.H., Bazotte R.B. \& Souza R.R. 1997. Morphological and quantitative analysis of the neurons of the myenteric plexus of the cecum of streptozotocin-induced diabetic rats. Arq. Neropsiquiatr. 55:696-702.

Zanoni J.N., Hernandes L., Bazotte R.B. \& Miranda-Neto M.H. 2002. Terminal ileum submucous plexus: a study of the vip-ergic neurons of diabetic rats treated with ascorbic acid. Arq. Neuro-Psquiatr. 60(1):3237.

Zanoni J.N., Buttow N.C., Bazotte R.B. \& Miranda-Neto M.H. 2003. Evalution of the population of nadph-diaphorase-stained and myosin$\mathrm{V}$ myenteric neurons in the ileum of chronically streptozocin-diabetic rats treated with ascorbic acid. Autonomic Neuroscience 104(1):3238. 